\title{
PEER-TO-PEER LENDING PLATFORM: FROM SUBSTITUTION TO COMPLEMENTARY FOR RURAL BANKS
}

\author{
Cliff KOHARDINATA ${ }^{\circledR 1}$, Novrys SUHARDIANTO ${ }^{\circledR 2}$, Bambang TJAHJADI® ${ }^{*}$ \\ ${ }^{1}$ Faculty of Economics and Business, Universitas Airlangga, Surabaya, Indonesia \\ ${ }^{1}$ Faculty of Management and Business, Universitas Ciputra, Surabaya, Indonesia \\ 2, ${ }^{3}$ Faculty of Economics and Business, Universitas Airlangga, Surabaya, Indonesia
}

Received 29 April 2020; accepted 26 June 2020

\begin{abstract}
This study aims to examine the impact of the growth of peer-to-peer (P2P) lending on the growth of rural bank lending. Further, this study investigates the outcome of the partnership agreement between the Rural Bank Association and Financial Technology (FinTech) Association in the last quarter of 2017 on the effect of P2P lending on rural bank lending by analyzing the impact separately in 2018 and 2019. The publicly available data from the Financial Services Authority and Bank of Indonesia were examined using panel data regression. The results show that P2P lending's growth is a substitute for the growth of the rural bank loan in 2018. However, the partnership between the Rural Bank Association and FinTech Association changed the effect of substitution into complementary in 2019. Moreover, the impact of P2P lending was more prominent in provinces with a higher number of rural banks and regions with lower economic growth. The restricted number of publicly available data becomes the limitation of this study to obtain the best results.
\end{abstract}

Keywords: banking, rural bank, FinTech, P2P lending, substitution, complementary.

JEL Classification: G21, G23, O33.

\section{Introduction}

Innovation strategy cannot be separated from technological aspects, which is also the critical element of a strategic information system, and still contains a considerable opportunity to improve an organization's performance (Hariyati et al., 2019). FinTech has a unique role in modernizing the financial system, which also helps to improve financial activity and increase profitability. FinTech could revolutionize the future of the banking industry as it will not rely heavily on brick-and-mortar branches (Azarenkova et al., 2018; Coetzee, 2018; Wonglimpiyarat, 2017). One of the fastest-growing financial services innovation through financial technology is the P2P platform, which facilitates online intermediation between those who need funding and those who have the funds (Ramlall, 2018). The banking sector has recently faced a new round with the emergence of FinTech (P2P) start-up companies (Stern et al., 2017).

P2P lending has gained a faster lending market, especially in developing countries, because developing countries have lower financial product penetration due to the lack of banking habits and geographical challenges. This situation has resulted in a higher cost of service and physical requirements mandated by the regulator. However, the existence of mobile technology helps the country to provide a necessary financial service (Gupta \& Xia, 2018; Stern et al., 2017). Indonesia is one of the countries that also have a significant market share for $\mathrm{P} 2 \mathrm{P}$ platforms, as shown by the continuous growth of $\mathrm{P} 2 \mathrm{P}$ lending in Indonesia. P2P platforms can help the Indonesian government to increase financial inclusion, but this does not mean that a P2P platform is not a threat to banks.

In the past, the intermediary function of $\mathrm{P} 2 \mathrm{P}$ platforms was carried out by banks and other financial institutions; hence P2P can have an impact on the banking sector performance. However, previous research on the effect of P2P platforms on the banking sector has shown mixed results. Zhang et al. (2019) show that P2P lending complements to bank lending in the initial regime, where the $\mathrm{P} 2 \mathrm{P}$ lending balance is still low. In subsequent regimes, when $\mathrm{P} 2 \mathrm{P}$ lending increases, P2P credit serves as a substitute for the bank loan. Members of the financial service industries believe that the rapid growth of FinTech can be a threat to the banking industry and may negatively affect

${ }^{*}$ Corresponding author. E-mail: bambang.tjahjadi@feb.unair.ac.id 
the banking performance. In contrast, others believe that the challenges of FinTech can be seen as opportunities to provide more flexibility, better functionality, and increase services (Phan et al., 2019; Romānova \& Kudinska, 2017). Also, P2P lending serves as a substitute for bank loans in terms of serving infra-marginal bank credit, but complementing bank loans in terms of small loans (Tang, 2019). The impact of P2P lending on the banking sector is still unclear; thus, it is crucial to examine and to continually explore the topic, considering the banking sector an essential part of every country.

The purpose of this study is to examine the impact of P2P lending growth on rural bank loan growth. Rural banks are a type of bank in Indonesia that operates conventionally, primarily serving the rural market, and do not offer payment service; thus, the banking activity is narrower compared to commercial banks. The limited operations and the small number of loan distribution in rural banks raise essential questions about the impact of P2P lending on the performance of rural banks in Indonesia.

The Rural Bank Association took a strategic move in the last quarter of 2017 by signing a partnership agreement with the Indonesian FinTech Association, especially to collaborate in terms of raising and channeling funds and improving its technology service (Fintech Indonesia, 2017). The immediate impact of the collaboration is on the association level. However, it may not be able to be implemented directly and simultaneously at the firm level (bank), especially in the subsequent year after the agreement was signed, so that rural banks would likely still maintain the status quo in 2018. Therefore, this study conducts a separate investigation for the initial year (2018) and the subsequent year after the partnership was signed (2019).

This study complements the past literature that discusses consumer theory and disruptive innovation in the banking sector, especially those related to the emergence of P2P platforms. Most of the previous studies examine only the impact P2P lending on bank lending exclusively focused on commercial banks (Phan et al., 2019; Tang, 2019; Zhang et al., 2019). Therefore, this study fills this literature gap by providing empirical evidence concerning the impact of P2P lending on the rural bank loan. The emergence of $\mathrm{P} 2 \mathrm{P}$ platforms may threaten or help rural banks because they serve a similar market, which is a small loan market. However, so far, there is no research to examine the impact of P2P lending on rural bank lending.

Practically, this research is useful to rural banks or small banks, because this research shows that P2P platforms can be as a competitor for rural banks. Furthermore, this research proves that the partnership between P2P platforms and rural banks can change a threat into an opportunity. On the other side, commercial banks or incumbents should be vigilant about any future disruptor, because the partnership between P2P platforms with rural banks looks like the pattern of disruptive innovation that starts from the low market, such as a rural market served by rural banks. Moreover, regulators should create policies that support $\mathrm{P} 2 \mathrm{P}$ companies to cooperate with rural banks or other small banks so that those banks can survive in the banking sector competition. The government needs to improve its infrastructure to facilitate the people, especially in rural areas, to be able to promote and utilize FinTech.

This research is presented in four main parts. The first part introduces and motivates the research problems. The second section describes a literature review that supports this study. Third, we present the research methods and data. Next, we explain the results of research and discussion. Finally, we provide a conclusion.

\section{Literature review}

In this section, there is a substantial body of literature used to understand the impact of P2P lending growth on rural bank loans. We divide literature review into three streams, the first focuses on introducing FinTech and P2P, the second explains the disruptive innovation, and the third focuses on consumer theory.

\subsection{FinTech and $P 2 P$}

FinTech is perceived as one of the most important innovations within the financial sector and is proliferating driven by information technology, favorable regulation, and a sharing economy (Lee \& Shin, 2018). The term "FinTech" is a neologism from the words' financial" and "technology" which represents the connection of the modern. FinTech is defined as innovative financial products or services delivered via technology (Gomber et al., 2017; Zalan \& Toufaily, 2017). FinTech emerges and evolves rapidly in diverse business models to solve problems that occur in the financial markets (Liu et al., 2020). FinTech is a technology-based innovation that plays a role in changing the current and future banking and financial landscape.

FinTech start-up businesses enter the financial domain and grab clients that have been served by traditionally established financial business. There are three main reasons why this occurs: first, FinTech start-up businesses offer new services/products and solutions to fulfill customers' needs that have previously been ignored by incumbents. Second, FinTech start-up businesses have made new opportunities for selling services and products through the application of new concepts and technologies. Third, information technology firms are better suited to produce products and services in an exceedingly highly innovative environment. Because development and changes within the information and communication technologies can be very dynamic and fast, companies must be creative and agile. FinTech firms concentrate on cost-efficient and affordable internet-based business models, and they are innovative and agile enough to attack incumbents (Gomber et al., 2017).

$\mathrm{P} 2 \mathrm{P}$ lending is a recent trend in FinTech that allows individuals and businesses to lend and borrow from each other through online P2P platforms or websites. FinTech 
lenders take advantage of alternative data, big data, and sophisticated artificial intelligence and machine learning algorithms to make fast credit decisions (Jagtiani \& John, 2018; Lee \& Shin, 2018). Generally, P2P firms use similar procedures to provide P2P lending services. Potential lenders and borrowers can make an account through the online platform's website before funding or posting a loan offer. Creditworthy borrowers are allowed to list their loan, which usually contains information about the loan, such as rate of interest, loan amount, the purpose of the loan, and other personal information about the borrower. Lenders can make a lending decision directly from a distance for the entire or a part of a loan offer based on the borrower information available in the database (Pengnate \& Riggins, 2020). P2P platforms as an alternative to traditional lending, P2P platforms bypass intermediation functions of financial services or banks to distribute credit.

\subsection{Disruptive innovation}

Financial innovations based on technology are widely believed to have a disruptive effect on the financial sector (Zalan \& Toufaily, 2017). Disruptive innovation has created a significant impact on academia and management practices and has the potential to change the way businesses operate and turn industries upside down (Lin et al., 2018; Rasool et al., 2018). Some authors, consultants, and researchers use "disruptive innovation" to explain a condition where industries suffer a shock or an incumbent that previously has been successful now stumbles in; however, this explanation is too broad to be applied (Christensen et al., 2015). Disruptive innovation differs from other theories that change the pattern of industrial competitions; each innovation theory has a unique strategic approach. Disruption is a process whereby a smaller company with fewer resources successfully challenges incumbent companies. Incumbent companies focus on improving their service and product that are most wanted by their customers while ignoring the needs of other market segments (Christensen et al., 2016; Christensen et al., 2015). A disrupter creates a new market that previously never existed and changes non-consumers into consumers (Christensen et al., 2015). Non-established market players that are new to the market are often the main initiators of disruptive innovations (Das et al., 2018).

Figure 1 shows the process of disruptive innovation; in the first phase, the pace of technological advances exceeds the growth in market demand for higher-performing technology. As a result, incumbents can serve the market excessively via producing higher-quality products (incumbent sustaining trajectory) that are more advanced than customers' needs. In turn, incumbents create a gap at the lower market level between the performances demanded by the customer to that provided by the company (Christensen et al., 2016). The gap offers opportunities to entrant companies to enter the market that has been neglected by the incumbent companies; the new entrant firms with disruptive innovation tend to relate with what is called a "low attack" that targets customers in low-end markets (Christensen et al., 2015; Montgomery et al., 2018). In the second phase, the disrupter steadily improves their performance and quality to move up in the mainstream market (Anagnostopoulos, 2018; Montgomery et al., 2018). In the third phase, the disruptive innovation achieves an appropriate level of performance and quality meets their standards for the primary market (Montgomery et al., 2018), and the mainstream customers adopt the innovative products of the disrupter (Christensen et al., 2015). The phase of disruptive innovation from the low-end market to the mainstream market erodes the market share of incumbents, then decreases their profitability. The innovation may disrupt or even substitute the incumbent (Pérez et al., 2017).

Usually, most incumbent companies are not interested in developing and creating disruptive innovation for lower margin, smaller market, and lower quality services that are rarely used by customers of incumbent companies (Christensen et al., 2016). Incumbent banks lower their level of competition due to the weak incentives for bigger banks to aggressively compete in the rural areas because big banks can operate with lower efficiency in the rural markets (Cyree \& Spurlin, 2012; Pilloff, 1999). The rural

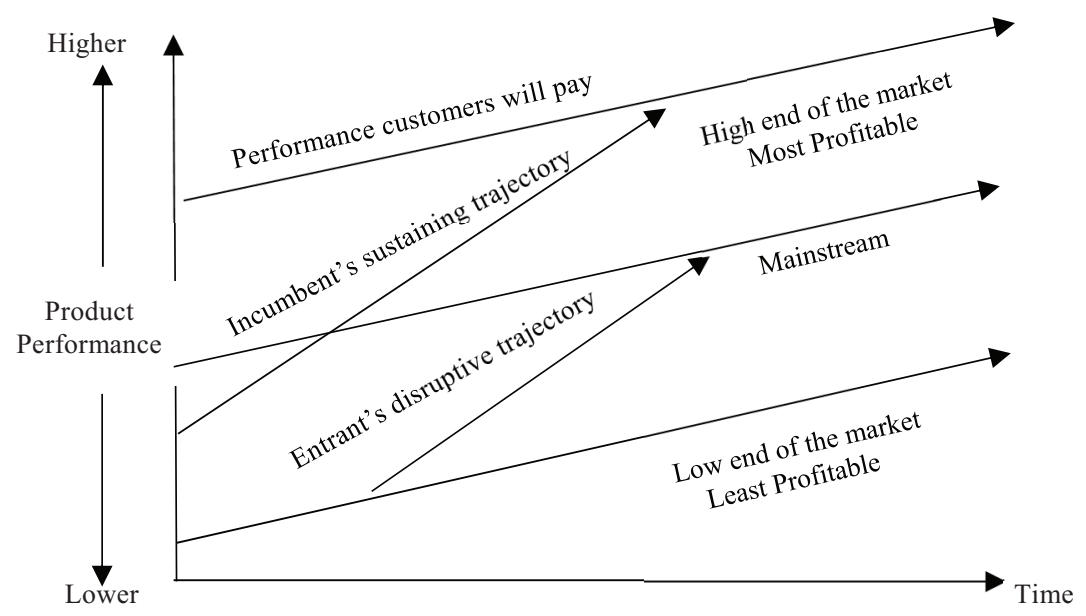

Figure 1. The Disruptive Innovation model (source: Christensen et al., 2015) 
banks' market usually consists of people from the rural community (remote areas), which is a small market for the incumbent banks; thus, rural banks do not threaten the incumbent banks or commercial banks. As a result, P2P platforms could enter the competition by reaching the rural markets (low-end market) whose target markets are ignored by the incumbent companies.

\subsection{Consumer theory}

From the perspective of consumer theory, a new service will act as a complementary service when being used with other services and may replace older services that meet the same needs (Aaker \& Keller, 1990; Levin \& Milgrom, 2004; Phan et al., 2019). Substitution products tend to have a universal application so that one product can replace other products and fulfill the same needs (Aaker \& Keller, 1990). Based on consumer theory, there is an opportunity for $\mathrm{P} 2 \mathrm{P}$ platforms to enter the rural market as substitute services or products for the rural banking sector. Technology is transforming financial services and creating new competitors outside the existing conventional segments (Goldstein et al., 2019). P2P platforms can act as complementary if they collaborate technology with rural banks to serve the low-end market, but can act as a substitute when they serve the same market with rural banks.

Literature suggests that a P2P platform is an effective complementary aspect of traditional banking and can be used to utilize idle funds in the community (Jiang et al., 2018; Li et al., 2017; Ma et al., 2018). However, P2P lending may not have any impact on the banking sector performance (Kohardinata et al., 2020; Li et al., 2017). One reason for this is the main customers of $\mathrm{P} 2 \mathrm{P}$ platforms usually cannot access the commercial loan (Thakor, 2020; Zhang et al., 2019). Thus, P2P lending platforms only serve a niche market and do not compete with the incumbent banks (Kohardinata et al., 2020; Zhang et al., 2019). Also, P2P platforms can serve other low-quality segment loans that are not reached by the banks (Tang, 2019). FinTechbased lenders may lessen the gaps in areas where there are only a limited number of banks, and the local economy condition is still a challenge. FinTech can be a new channel for people who are not covered by traditional banks (Jagtiani \& Lemieux, 2018; Li et al., 2017).

In line with the disruptive innovation theory (Christensen et al., 2015), entrants usually enter the market at the low-end market by serving customers that are not served by incumbents or known as a niche market (Minto et al., 2017). Rural markets give a small potential profit for big banks compared to their total profit, so it may not be worth the cost to design the service and products to fulfill the various needs of the small market (Pilloff, 1999). Thus, it opens a possibility for P2P companies as a complement to collaborate with rural banks to reach the rural markets, which are small or low markets. Another possible reason for FinTech as a complement to banks is that many banks have seen the significance of FinTech and tried to integrate these technologies or start-up FinTech companies into their businesses (Li et al., 2017).

Conversely, P2P platforms potentially may serve as a substitution for banks because they both have similarities; they both provide business loans and personal loans to their customers. A study by Phan et al. (2019) shows that the growth of FinTech harms the performance of the banking sector, which is also in line with a study by Zhang et al. (2019) which stated that, when P2P lending balance is more significant, the $\mathrm{P} 2 \mathrm{P}$ lending balance brings a negative impact to the domestic banks' loan balances. FinTech provides a technical solution, where FinTech-based companies are in a better position than the banks because FinTech faces fewer regulations and adequate technological support to come up with a better solution compared to the banks (Zalan \& Toufaily, 2017). With the rapid expansion of $\mathrm{P} 2 \mathrm{P}$ lending, as well as people's recognition of its importance and convenience while the banking sector still applies strict rules and is more cautious about each loan, the small and medium-sized businesses (SMEs) and individuals will find it difficult to get a loan from the bank. Thus, more people will shift towards P2P lending platforms, especially those who need fast and efficient loans (Kohardinata et al., 2020; Zhang et al., 2019). One of the potential benefits of expanding P2P lending is to increase access to banking services in areas with less banking competition, such as rural areas (Tang, 2019; Wolfe \& Yoo, 2017). However, rural markets generally are customers of rural banks, so that $\mathrm{P} 2 \mathrm{P}$ platforms potentially act as a substitution or competitor because they serve the same market.

\section{Research methodology and data}

This study used panel data regression, where the data are spanned from February 2018 to October 2019. At the end of 2017, the Indonesian FinTech Association signed a partnership agreement with the Indonesian Rural Banks Association, mainly for increasing the amount of funding and providing technological services, so that other rural banks that do not collaborate with a P2P platform might experience some pressure. The benefits of the partnership agreement between the FinTech Association and the Rural Banks Association may not be seen yet in 2018 because it requires a process and time to be implemented in the firm (bank) level. Thus, rural banks are still likely to maintain their status-quo in 2018. Therefore, this study decided to conduct separate testing for the years 2018 and 2019. The model used to test the impact of P2P on the growth of rural bank loans is as follows:

$$
\Delta L O A N R B_{i t}=+1 P 2 P_{j t}+2 L O A N C B_{i t}+3 M 2_{t}+D R B+{ }_{i j t} .
$$

Table 1 shows 33 provinces in Indonesia that separated into Java Island and Non-Java Island. The detailed description of the testing model (1) is explained further in Table 2 . The subscript $i$ indicates provinces, $j$ indicates the island 
(Java Island and outside Java Island), $t$ shows the month, and $\varepsilon_{i j t}$ explains the random error, which includes specific information from banks that are not included in the study. Variable $\Delta \mathrm{LoanRB}_{i, t}$ is the percentage (\%) monthly growth of rural bank loans in each of the 33 provinces as displayed in Table $1, \Delta \mathrm{P} 2 \mathrm{P}_{j t}$ is the percentage (\%) monthly growth of P2P lending (real growth) in each island (Java and Non-Java Island). The use of growth in this study is to indicate the time-differenced specification. It mitigates biases from unobserved characteristics such as time-invariant factors in the province or the island (Doan et al., 2015; Nguyen et al., 2017).

Table 1. Provinces in Java and Non-Java Island (source: Zakky, 2018)

\begin{tabular}{|l|l|}
\hline \multicolumn{1}{|c|}{ Island } & \multicolumn{1}{|c|}{ Provinces } \\
\hline Java & $\begin{array}{l}\text { D. I Yogyakarta, DKI Jakarta, West Java, } \\
\text { Banten, East Java, Central Java. }\end{array}$ \\
\hline Outside Java & $\begin{array}{l}\text { Bali, Bengkulu, North Sumatera, West } \\
\text { Sumatera, South Sumatera, West Papua, } \\
\text { Papua, Lampung, Riau, Riau Islands, Bangka } \\
\text { Belitung, Central Sulawesi, North Sulawesi, } \\
\text { Southeast Sulawesi, South Sulawesi, West } \\
\text { Sulawesi, Gorontalo, Jambi, Aceh, West } \\
\text { Nusa Tenggara, East Nusa Tenggara, North } \\
\text { Maluku, Maluku, West Kalimantan, East } \\
\text { Kalimantan, Central Kalimantan, South } \\
\text { Kalimantan. }\end{array}$ \\
\hline
\end{tabular}

Table 2. Variable and measurement (source: authors' compilation)

\begin{tabular}{|l|l|}
\hline \multicolumn{1}{|c|}{ Variable } & \multicolumn{1}{c|}{ Measurement } \\
\hline \multicolumn{2}{|c|}{ Dependent Variable } \\
\hline $\begin{array}{l}\text { Rural bank loans } \\
(\Delta \text { LoanRB })\end{array}$ & $\begin{array}{l}\text { Monthly growth of rural bank loans in } \\
\text { each province. }\end{array}$ \\
\hline \multicolumn{2}{|c|}{ Independent Variable } \\
\hline $\begin{array}{l}\text { P2P lending } \\
(\Delta \text { P2P })\end{array}$ & $\begin{array}{l}\text { Monthly growth of the accumulation of } \\
\text { P2P lending (real growth) on each island } \\
\text { (Java and Non-Java Island) }\end{array}$ \\
\hline \multicolumn{2}{|c|}{ Control Variable } \\
\hline $\begin{array}{l}\text { Commercial Bank } \\
\text { loans ( } \Delta \text { LoanCB })\end{array}$ & $\begin{array}{l}\text { Monthly growth of commercial bank } \\
\text { loans in each province. }\end{array}$ \\
\hline $\begin{array}{l}\text { Money supply } \\
(\Delta \text { M2) }\end{array}$ & $\begin{array}{l}\text { Monthly growth of money supply in } \\
\text { Indonesia. }\end{array}$ \\
\hline $\begin{array}{l}\text { Dummy High Low } \\
\text { Rural Bank Loans } \\
(\text { DRB })\end{array}$ & $\begin{array}{l}\text { Dummy variable value equals to 1 } \\
\text { indicates that the growth of the rural } \\
\text { bank loans is larger than the growth of } \\
\text { commercial bank loans, and 0 otherwise. }\end{array}$ \\
\hline
\end{tabular}

The control variable applied in this study is the $\Delta$ LoanCBit, which is the percentage (\%) monthly growth of commercial bank loans in each of the 33 provinces, as displayed in Table 1, as a representation of banks that have dominated the credit market in Indonesia (incumbent). This research also includes a macro variable $\Delta M 2 t$, which explains the percentage (\%) of the monthly growth of money supply in Indonesia. Moreover, a dummy variable $(D R B)$ is used to categorize the growth of credits in rural banks, whether it is higher or lower than the growth of loans in commercial banks.

Data panel regression consists of pooled ordinary least squares $(O L S)$, fixed effect, and random effect. F-test and the Hausman test are applied to test the most appropriate model between the random effect and fixed effect model (Dang, 2019). If the results of the F-test and Hausman test show that random effect is the most suitable model, then we continue to use the LaGrange Multiplier to test the most appropriate model between pooled OLS and random effect (Shawtari, 2018). Autocorrelation and heteroscedasticity problems could be detected and solved by robust standard errors (Hoechle, 2007).

We perform several analyses to check the robustness of our result findings; the concentrated banking sector should be encouraged to diversify its banking network geographically so that it can increase the banks' competitiveness (Pham et al., 2019). The high number of rural banks in each province may potentially bias the result of the study because an area with more rural banks will have higher competition tension among rural banks. They may increase and widen access for customers to get credit so that the growth of P2P lending will only be concentrated on areas with a small number of rural banks. Therefore, the number of rural bank offices (RBO) is added as a control variable in the robustness test. Moreover, robustness tests are conducted by separating provinces in Indonesia that have lower and higher rural bank offices than the median. We also do another robustness test that separates the data based on more inferior provincial economic (gross domestic product by province) growth and the higher ones, with the median as the cut-off point.

\section{Research results and discussion}

\subsection{Descriptive statistics}

Panel A in Table 3 summarizes the descriptive statistics data in 2018, where the growth data were obtained from February to December 2018 or 11 months $(T=11)$, with a total observation of $363(N=363)$, which includes 33 provinces in Indonesia $(n=33)$. On average, the growth of loans in rural banks $(\triangle$ LoanRB $)$ is 0.0102 and varies between -0.0796 to 0.1272 . The average real growth of $\mathrm{P} 2 \mathrm{P}$ lending $(\triangle \mathrm{P} 2 \mathrm{P})$ is 0.2078 , with a minimum value of 0.0140 and a maximum value of 0.7694 . The average growth of commercial bank loans $(\triangle \operatorname{Loan} C B)$ is 0.0094 , ranging from -0.1260 to 0.0732 . The average of the money supply variable $(\Delta M 2)$ is 0.0067 , with a minimum value of -0.0048 and a maximum value of 0.0182 . Lastly, the mean of the dummy variable (DRB), the high-low indicators of the growth of rural bank loans, is 0.4683 .

Panel B in Table 3 shows the descriptive statistic data from January to October $2019(T=10)$ in 33 provinces in Indonesia $(n=33)$, with a total observation of 330 $(N=330)$. The average growth of loans in rural banks $(\triangle$ LoanRB) is 0.0099 and varies between -0.0379 to 0.0781 . The real growth loan of $\mathrm{P} 2 \mathrm{P}(\Delta \mathrm{P} 2 \mathrm{P})$ has an average 
of 0.1215 , with a minimum value of 0.0906 and a maximum of 0.1683 . The average growth of commercial bank loan $(\triangle \operatorname{Loan} C B)$ is 0.0061 , with a minimum of -0.0781 and a peak of 0.0799 . The average of money supply $(\Delta M 2)$ is 0.0046 with a minimum value of -0.0199 and a maximum value of 0.0198 , and the mean of the dummy variable $(D R B)$ is 0.5515 .

Table 3. Descriptive statistics (source: authors' calculation)

\begin{tabular}{|l|c|c|c|c|}
\hline \multicolumn{5}{|c|}{ Panel A: In 2018} \\
\hline \multicolumn{1}{|c|}{ Variable } & Mean (1) & Std Dev (2) & Min (3) & Max (4) \\
\hline$\Delta$ LoanRB & 0.0102 & 0.0178 & -0.0796 & 0.1272 \\
\hline$\Delta \mathrm{P} 2 \mathrm{P}$ & 0.2078 & 0.1731 & 0.0140 & 0.7694 \\
\hline$\Delta$ LoanCB & 0.0094 & 0.0142 & -0.1260 & 0.0732 \\
\hline$\Delta$ M2 & 0.0067 & 0.0069 & -0.0048 & 0.0182 \\
\hline DRB & 0.4683 & 0.4997 & 0 & 1 \\
\hline \multicolumn{5}{|c|}{ Panel B: In 2019 } \\
\hline Variable & Mean (1) & Std Dev (2) & Min (3) & Max (4) \\
\hline$\Delta$ LoanRB & 0.0099 & 0.0144 & -0.0379 & 0.0781 \\
\hline$\Delta \mathrm{P} 2 \mathrm{P}$ & 0.1215 & 0.0216 & 0.0906 & 0.1683 \\
\hline$\Delta$ LoanCB & 0.0061 & 0.0136 & -0.0781 & 0.0799 \\
\hline$\Delta$ M2 & 0.0046 & 0.0102 & -0.0199 & 0.0198 \\
\hline DRB & 0.5515 & 0.4981 & 0 & 1 \\
\hline
\end{tabular}

The mean of each variable in Table 3 panel A and panel B shows positive monthly growth. It relatively varies, as shown by the standard deviation and the range between the minimum and maximum values. Still, the mean monthly growth of each variable decreases when compared between 2018 to 2019 .

\subsection{Model testing and research results}

This section explains further about the testing to determine the model used in this research. Hence, this study presents the result of model testing.

\subsubsection{Model testing}

Columns 1 and 2 in Table 4 show the result of model testing applied to understand the data obtained from 2018 and 2019. The result of Prob $>F$ (Chow Testing) in 2018 and 2019 is less than 0.05 , which indicates that the fixed effect is more appropriate to estimate panel data regression.

Table 4. Chow test, Hausman tests, and Variance Inflation Factor (source: authors' calculation)

\begin{tabular}{|l|c|c|}
\hline & $2018(1)$ & $2019(2)$ \\
\hline Prob > F (Chow Test) & $0.0029^{* * *}$ & $0.0000^{* * *}$ \\
\hline Hausman Test & $0.0000^{\star * *}$ & $0.0263^{* *}$ \\
\hline $\begin{array}{l}\text { VIF (Variance Inflation } \\
\text { Factor) }\end{array}$ & 1.52 & 2.39 \\
\hline
\end{tabular}

Note: ${ }^{* *}$ significant at the 0.01 level, ${ }^{* *}$ significant at the 0.05 level.
The Hausman test is used to choose between a fixed effect and random effect, and the results presented in Table 4 columns 1 and 2 are below 0.05 . Thus, regression testing on the data panel was conducted using a fixed effect. The multicollinearity test in Table 4 shows a relatively low variance inflation factor (VIF). Thus, it can be concluded that there is no multicollinearity problem.

It is essential to ensure that the statistical test is valid. Robust standard error was conducted for all models to overcome any heteroscedasticity and autocorrelation issue, so that the result of the study will be more robust (Shawtari, 2018).

\subsubsection{Results}

The results of equation (1) are presented in Table 5. The growth of P2P lending in 2018 has a negative impact on the growth of loans in rural banks with a significance level of $10 \%(\beta=-0.0044, p$-value $=0.078)$. Meanwhile, loans from commercial banks have a positive impact on rural banks with a significance of $1 \%(\beta=0.2479, p$-value $=$ 0.002 ). Money supply (M2) does not have a significant effect impact towards the growth of loans in rural banks $(\beta=0.0173, p$-value $=0.892)$, and a dummy variable $(\mathrm{DRB})$ has a significant effect $(\beta=0.0197, p$-value $=0.000)$ and the $R$ square is $34.67 \%$.

Table 5. Regression analysis result between variables in 2018 and 2019 (source: authors' calculation)

\begin{tabular}{|l|c|c|}
\hline \multirow{3}{*}{ Variable } & $\Delta \operatorname{LoanRB}(1)$ & $\Delta$ LoanRB $(2)$ \\
\cline { 2 - 3 } & 2018 & 2019 \\
\hline \multirow{2}{*}{$\Delta \mathrm{P} 2$ P lending } & $-0.0044^{*}$ & $\begin{array}{c}0.0648^{* *} \\
(0.040)\end{array}$ \\
\hline \multirow{2}{*}{$\Delta$ LoanCB } & $\begin{array}{c}0.2479^{* * *} \\
(0.002)\end{array}$ & $\begin{array}{c}0.3678^{* * *} \\
(0.000)\end{array}$ \\
\hline \multirow{2}{*}{$\Delta M 2$} & 0.0173 & $\begin{array}{c}0.2797^{* * *} \\
(0.008)\end{array}$ \\
\hline \multirow{2}{*}{ DRB } & $(0.892)$ & $0.0184^{* * *}$ \\
& $0.0197^{* * *}$ & $(0.000)$ \\
\hline \multirow{2}{*}{ Constant } & $(0.000)$ & $-0.01167^{* * *}$ \\
& -0.0006 & $(0.001)$ \\
\hline$R$ Square & $(0.778)$ & 0.4526 \\
\hline
\end{tabular}

Note: ${ }^{* * *}$ significant at the 0.01 level, ${ }^{* *}$ significant at the 0.05 level, * significant at the 0.10 level.

The impact of P2P lending growth on rural bank loan growth in 2019 is shown to be positive $(\beta=0.0648$, $p$-value $=0.040$ ); loans from the commercial banks are consistent with 2018, which have a positive impact on rural banks with a significance of $1 \%(\beta=0.3678$, $p$-value $=0.000)$. Money supply $(M 2)$ also has a positive effect towards the growth of rural bank loans $(\beta=$ $0.2797, p$-value $=0.008)$, and a dummy variable $(D R B)$ has a significant effect $(\beta=0.0184, p$-value $=0.000)$ and the $R$ square is $45.26 \%$.

The results presented in Table 5 show that the growth of P2P lending in 2018 negatively affects the growth of 
rural bank lending. In other words, $\mathrm{P} 2 \mathrm{P}$ loans substitute rural bank loans. However, after the partnership agreement takes effect, the growth of $\mathrm{P} 2 \mathrm{P}$ credit has a positive impact on the growth of rural bank lending in 2019. Therefore, the collaboration agreement changes the effect of P2P loan on rural bank loan from substitution into complementary.

\subsection{Discussion}

The empirical test presented in Table 5 column 1 shows that the growth of P2P lending in 2018 negatively impacts the growth of rural bank loans, meaning that it has a substitution effect. This finding indicates that the partnership between the Indonesian FinTech Association and the Indonesian Rural Bank Association did not show optimal results in 2018. Hence, the P2P platforms are competitors to rural banks because they have the same target market. In this period, the disruptive innovation begins to enter the market from the low-end market. The result also indicates that, if $\mathrm{P} 2 \mathrm{P}$ platforms do not pay attention to smaller banks, such as rural banks, P2P can be a competitor that can replace the role of rural banks, especially in lending money to the community. A possible reason that may cause a substitution manner is that $\mathrm{P} 2 \mathrm{P}$ platforms can provide accessible, cost-effective, time-saving products, and fewer loan regulations compared to the product served by rural banks. Moreover, the range of rural banks is still limited by brick and mortar, so that people with an internet connection can obtain credit from P2P platforms quickly and flexibly, compared to accessing the limited facilities of the rural bank.

Collaboration at the association level between FinTech and rural bank associations requires a process and time to be implemented at a firm (bank) level. The effect of the collaboration is starting to be apparent in 2019, as shown in the empirical test in column 2 of Table 5, which shows the positive impact of peer-to-peer lending growth on the rural bank loan growth. Thus, it can be inferred that the credit distribution partnership by FinTech can change the substitution effect to be a complementary effect to rural banks. It is reasonable to have a collaboration between P2P platforms with rural banks, especially in terms of loans to deposit ratio (LDR). Figure 2 shows that the LDR of rural banks is still loose. The majority of annual LDR is under $80 \%$, while the LDR of commercial banks is too tight, and it reaches the peak in 2018 and October 2019, which is $94.78 \%$ and $93.96 \%$, respectively. The complementary effect of P2P platforms to rural banks becomes an interesting study, which shows that P2P technology can collaborate to help small banks (rural banks) to survive from the competition in the banking sector.

The results in columns 1 and 2 of Table 5 show that the growth of commercial bank loans does not hurt the growth of rural bank loans. It means that rural banks have a different customer segment to commercial banks. However, the complementary effect of $\mathrm{P} 2 \mathrm{P}$ platforms and rural banks through partnership can potentially become disruptive for traditional commercial banks in the future. From the perspective of disruptive innovation theory, a disruptive technology is initially an inferior process compared to performance valued by mainstream customers. However, it has disruptive characteristics that are appreciated by the non-consumers in the low-end market or new market that is cheaper and more convenient to use (Christensen et al., 2015; Hang et al., 2011). In line with the process of disruptive innovation, the collaboration between P2P platforms and rural banks indeed serves the rural market, low-end markets that are not the main target of commercial banks, by which P2P platforms then have the potential to penetrate the mainstream and high-end market.

Incumbent banks (commercial banks) should immediately respond to the presence of $\mathrm{P} 2 \mathrm{P}$ platforms that have just begun and show rapid growth, because, once FinTech reaches the primary banking market, banking management will struggle to face the competition. Zhang et al. (2019) said that the lower amount of P2P lending has a positive impact on commercial banks; however, for subsequent regimes, when P2P credit gets bigger, it may bring a negative effect towards bank loans. As a result, $\mathrm{P} 2 \mathrm{P}$ platforms become a small giant that has the potential

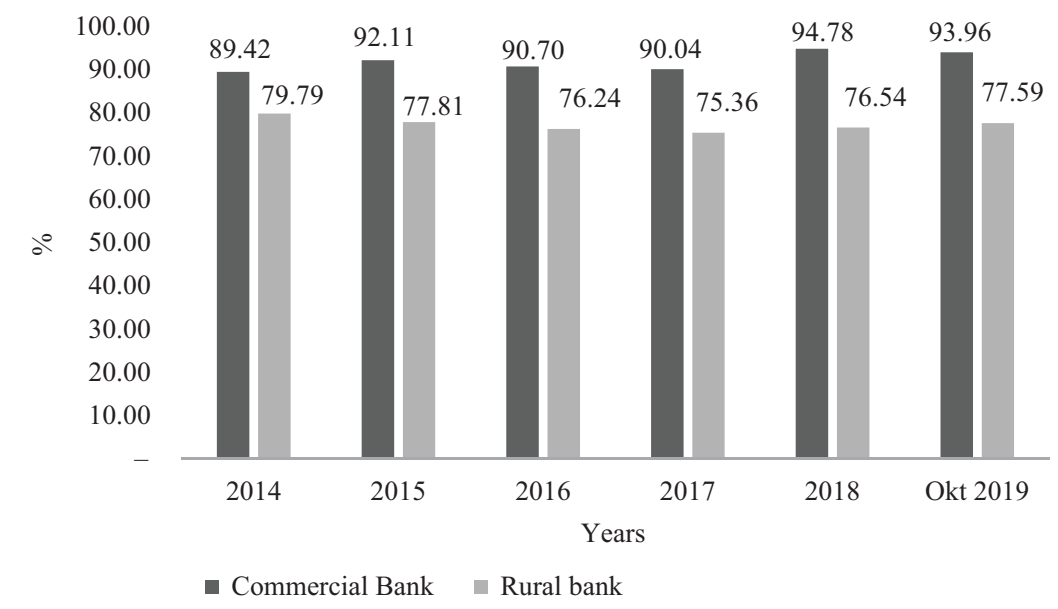

Figure 2. Loan to Deposit Ratio (LDR) Commercial Bank and Rural Bank in Indonesia for Period 2012-Oct 2019 (source: Otoritas Jasa Keuangan [OJK], 2019) 
Table 6. The result of robustness tests by adding the number of rural bank offices and separating their low-high number (source: authors' calculation)

\begin{tabular}{|c|c|c|c|c|c|c|}
\hline \multirow{4}{*}{ Variable } & \multicolumn{2}{|c|}{$\triangle$ LoanRB } & \multicolumn{2}{|c|}{$\Delta$ LoanRB } & \multicolumn{2}{|c|}{$\Delta$ LoanRB } \\
\hline & 2018 & 2019 & 2018 & 2019 & 2018 & 2019 \\
\hline & \multicolumn{2}{|c|}{$R B O$} & \multicolumn{2}{|c|}{ Low $R B O$} & \multicolumn{2}{|c|}{ High $R B O$} \\
\hline & (1) & (2) & (3) & (4) & (5) & (6) \\
\hline$\Delta \mathrm{P} 2 \mathrm{P}$ lending & $\begin{array}{c}-0.0043^{\star} \\
(0.083)\end{array}$ & $\begin{array}{c}0.0647^{\star *} \\
(0.040)\end{array}$ & $\begin{array}{c}-0.00174 \\
(0.630)\end{array}$ & $\begin{array}{l}0.0322 \\
(0.421)\end{array}$ & $\begin{array}{c}-0.00532^{\star *} \\
(0.044)\end{array}$ & $\begin{array}{l}0.0882^{\star *} \\
(0.038)\end{array}$ \\
\hline$\triangle \operatorname{Loan} C B$ & $\begin{array}{c}0.2493^{* * *} \\
(0.002)\end{array}$ & $\begin{array}{c}0.3681^{* * *} \\
(0.000)\end{array}$ & $\begin{array}{c}0.22258^{\star *} \\
(0.024)\end{array}$ & $\begin{array}{l}0.5704^{* * *} \\
(0.000)\end{array}$ & $\begin{array}{c}0.33421^{\star * *} \\
(0.000)\end{array}$ & $\begin{array}{c}0.2102^{\star *} \\
(0.050)\end{array}$ \\
\hline$\Delta M 2$ & $\begin{array}{l}0.0124 \\
(0.923) \\
\end{array}$ & $\begin{array}{c}0.2810^{* * *} \\
(0.008)\end{array}$ & $\begin{array}{c}-0.04389 \\
(0.801)\end{array}$ & $\begin{array}{l}0.0964 \\
(0.302) \\
\end{array}$ & $\begin{array}{c}0.0113952 \\
(0.915)\end{array}$ & $\begin{array}{c}0.4075^{\star * *} \\
(0.003)\end{array}$ \\
\hline$D R B$ & $\begin{array}{c}0.0199^{* * *} \\
(0.000)\end{array}$ & $\begin{array}{c}0.0184^{* * *} \\
(0.000)\end{array}$ & $\begin{array}{c}0.02766^{* * *} \\
(0.000)\end{array}$ & $\begin{array}{c}0.0239^{* * *} \\
(0.000)\end{array}$ & $\begin{array}{c}0.01231^{* * *} \\
(0.000)\end{array}$ & $\begin{array}{c}0.01317^{\star * *} \\
(0.000) \\
\end{array}$ \\
\hline$R B O$ & $\begin{array}{c}0.0002^{\star *} \\
(0.027)\end{array}$ & $\begin{array}{c}-7.90 \mathrm{e}-06 \\
(0.518)\end{array}$ & - & - & - & - \\
\hline R Square & 0.0003 & 0.4219 & 0.4173 & 0.5252 & 0.4081 & 0.4522 \\
\hline Constant & $\begin{array}{c}-0.03768^{\star *} \\
(0.031)\end{array}$ & $\begin{array}{c}-0.0102^{\star *} \\
(0.023)\end{array}$ & $\begin{array}{c}-0.00259 \\
(0.410)\end{array}$ & $\begin{array}{c}-0.0106^{* *} \\
(0.037)\end{array}$ & $\begin{array}{c}0.00137 \\
(0.405)\end{array}$ & $\begin{array}{c}-0.01203^{* *} \\
(0.017)\end{array}$ \\
\hline
\end{tabular}

Note: ${ }^{\star * \star}$ significant at the 0.01 level, ${ }^{\star *}$ significant at the 0.05 level, ${ }^{\star}$ significant at the 0.10 level.

to grow as a big giant quickly. Commercial banks should be vigilant and should embrace and manage the existing P2P platforms.

\subsection{Robustness test}

The robustness test in columns 1 and 2 of Table 6 shows that the including variable of the number of rural bank office $(\mathrm{RBO})$ in the model does not change the main results. The growth of P2P lending negatively affects the rural bank loan in 2018 with a significance level of $10 \%$, but it positively influences the rural bank loan in 2019 . Table 6 columns 3 to 6 shows that the effect of P2P lending

Table 7.The Result of robustness tests by separating low-high economic growth (source: authors' calculation)

\begin{tabular}{|c|c|c|c|c|}
\hline \multirow{4}{*}{ Variable } & \multicolumn{2}{|c|}{$\triangle \operatorname{LoanRB}$} & \multicolumn{2}{|c|}{$\Delta \operatorname{LoanRB}$} \\
\hline & 2018 & 2019 & 2018 & 2019 \\
\hline & \multicolumn{2}{|c|}{ Low Economic Growth } & \multicolumn{2}{|c|}{ High Economic Growth } \\
\hline & (1) & (2) & (3) & (4) \\
\hline $\begin{array}{l}\Delta \mathrm{P} 2 \mathrm{P} \\
\text { lending }\end{array}$ & $\begin{array}{l}-0.0104^{\star *} \\
(0.018)\end{array}$ & $\begin{array}{c}0.1045^{\star *} \\
(0.032)\end{array}$ & $\begin{array}{c}0.00003 \\
(0.995)\end{array}$ & $\begin{array}{l}0.0730 \\
(0.104)\end{array}$ \\
\hline$\triangle$ Loan $C B$ & $\begin{array}{l}0.2961^{\star *} \\
(0.043)\end{array}$ & $\begin{array}{c}0.2773^{\star *} \\
(0.013)\end{array}$ & $\begin{array}{c}0.2836^{\star * *} \\
(0.000)\end{array}$ & $\begin{array}{c}0.4760^{\star * *} \\
(0.000)\end{array}$ \\
\hline$\Delta M 2$ & $\begin{array}{c}-0.2052 \\
(0.262)\end{array}$ & $\begin{array}{c}0.3758^{* * *} \\
(0.001)\end{array}$ & $\begin{array}{l}0.2725 \\
(0.181)\end{array}$ & $\begin{array}{l}0.1665 \\
(0.113)\end{array}$ \\
\hline$D R B$ & $\begin{array}{c}0.0148^{* * *} \\
(0.000)\end{array}$ & $\begin{array}{c}0.0147^{* * *} \\
(0.000)\end{array}$ & $\begin{array}{c}0.0241^{* * *} \\
(0.000)\end{array}$ & $\begin{array}{c}0.0212^{\star * *} \\
(0.000)\end{array}$ \\
\hline$R$ Square & 0.3162 & 0.4061 & 0.4001 & 0.5079 \\
\hline Constant & $\begin{array}{l}0.0023 \\
(0.166)\end{array}$ & $\begin{array}{c}-0.0143^{* *} \\
(0.013)\end{array}$ & $\begin{array}{c}-0.0043 \\
(0.260)\end{array}$ & $\begin{array}{c}-0.0145^{\star x} \\
(0.013)\end{array}$ \\
\hline
\end{tabular}

Note: ${ }^{* *}$ significant at the 0.01 level, ${ }^{* *}$ significant at the 0.05 level, ${ }^{\star}$ significant at the 0.10 level. on rural bank loans is consistent with the main findings. The results hold in the provinces with a higher number of RBO (columns 5 and 6). Therefore, the effect of P2P credit expansion on rural bank loan tends to occur only in areas in which the borrowers already have access to bank credit (Tang, 2019).

The last robustness test (Table 7 in columns 1 and 2) suggests that the role of $\mathrm{P} 2 \mathrm{P}$ lending is prominent in areas with lower economic growth (gross domestic product) as the role of rural banks in such areas are more pronounced. The findings indicate that credit expansion of P2P affects the growth of rural bank loans in areas where the economic condition is more challenging, in which P2P lending has a negative impact in 2018 and turns to be positive in 2019. P2P platforms may gain market share in areas where economic variables show a more challenging environment (Jagtiani \& Lemieux, 2018).

\section{Conclusions}

This study aims to examine the impact of P2P lending growth on the growth of rural bank lending in the years of 2018 and 2019, respectively. The result of this study showed that P2P loan does have a negative or a substitution effect on the rural banks in 2018. Nevertheless, the collaboration between P2P platforms and rural banks has a positive or a complementary effect in 2019. The result of the robustness test by adding independent variables of the number of rural banks showed consistency with the main result that the growth of P2P lending in 2018 had a negative impact on the rural bank loans but turns into a positive impact in 2019. Moreover, second robustness tests showed that this finding holds in provinces with a higher number of rural banks and regions with lower economic growth. 
Theoretically, P2P platforms as a new entrant could potentially serve as disruptive innovation, and based on consumer theory, act as a substitution or complement to incumbents in the banking sector. Previous research on the impact of P2P lending on Bank loan only focuses on examining the effects on commercial banks. Therefore, our study fills the gap in the earlier studies by concerning the impact of P2P credit on the rural bank loan, in which the growth of P2P platforms may threaten rural banks because rural banks primarily serve a small rural market (low market), or P2P platforms can help to complement rural banks. To the best of our knowledge, there is no research examining the impact of $\mathrm{P} 2 \mathrm{P}$ lending on rural bank lending.

Practically, this research is useful to small banks, especially rural banks, to have an intensive collaboration with P2P platforms, because, if not, the P2P platform can be a strong competitor or may substitute rural banks, and vice versa. When P2P platforms collaborate with rural banks to serve the low-end market or markets neglected by commercial banks (incumbent), incumbent banks should be vigilant about any future disrupter. Hence, commercial banks should consider collaborating with P2P platforms or create a division that focuses on developing FinTech-based facilities. Furthermore, the government and regulators should develop policies that support P2P companies to work with rural banks or other small banks so that those banks can survive and compete in the banking sector competition. The government needs to improve its infrastructure to facilitate the people, especially those who live in rural areas, to be able to promote and use FinTech facilities.

The limited number of data obtained in this study becomes one of the limiting factors in achieving the best result. This limitation also brings difficulties to test other indicators that may affect the phenomena. For future research, this study suggests analyzing different countries, as each country has its own unique structure and community awareness towards technology. Also, future research can also investigate the impact of P2P lending growth towards other types of small financial institutions because $\mathrm{P} 2 \mathrm{P}$ platforms may be as competitors to the existence of a small financial institution if this threat not well-managed.

\section{References}

Aaker, D. A., \& Keller, K. L. (1990). Consumer evaluations of brand extensions. Journal of Marketing, 54(1), 27-41.

https://doi.org/10.2307/1252171

Anagnostopoulos, I. (2018). Fintech and regtech: Impact on regulators and banks. Journal of Economics and Business, 100, 7-25. https://doi.org/10.1016/j.jeconbus.2018.07.003

Azarenkova, G., Shkodina, I., Samorodov, B., \& Babenko, M. (2018). The influence of financial technologies on the global financial system stability. Investment Management and Financial Innovations, 15(4), 229-238.

https://doi.org/10.21511/imfi.15(4).2018.19

Christensen, C. M., Altman, E. J., Mcdonald, R., \& Palmer, J. (2016). Disruptive innovation: intellectual history and future paths (No. 17-057). Harvard Business School.
Christensen, C. M., Raynor, M., \& McDonald, R. (2015). What is disruptive innovation? Harvard Business Review, (December).

Coetzee, J. (2018). Strategic implications of fintech on South African retail banks. South African Journal of Economic and Management Sciences, 21(1).

https://doi.org/10.4102/sajems.v21i1.2455

Cyree, K. B., \& Spurlin, W. P. (2012). The effects of big-bank presence on the profit efficiency of small banks in rural markets. Journal of Banking and Finance, 36(9), 2593-2603. https://doi.org/10.1016/j.jbankfin.2012.05.015

Dang, V. D. (2019). The effects of loan growth on bank performance: Evidence from Vietnam. Management Science Letters, 9, 899-910. https://doi.org/10.5267/j.msl.2019.2.012

Das, P., Verburg, R., Verbraeck, A., \& Bonebakker, L. (2018). Barriers to innovation within large financial services firms: An in-depth study into disruptive and radical innovation projects at a bank. European Journal of Innovation Management, 21(1), 96-112. https://doi.org/10.1108/EJIM-03-2017-0028

Doan, T., Nguyen, S., Vu, H., Tran, T., \& Lim, S. (2015). Does rising import competition harm local firm productivity in less advanced economies? Evidence from the Vietnam's manufacturing sector. The Journal of International Trade \& Economic Development, (May), 37-41.

https://doi.org/10.1080/09638199.2015.1035739

Fintech Indonesia. (2017). Penandatanganan MoU dengan Perbarindo. https://fintech.id/events/penandatanganan-moudengan-perbarindo/

Goldstein, I., Jiang, W., \& Karolyi, G. A. (2019). To FinTech and beyond. Review of Financial Studies, 32(5), 1647-1661. https://doi.org/10.1093/rfs/hhz025

Gomber, P., Koch, J.-A., \& Siering, M. (2017). Digital finance and FinTech: current research and future research directions. Journal of Business Economics, 87(5), 537-580. https://doi.org/10.1007/s11573-017-0852-x

Gupta, A., \& Xia, C. (2018). A paradigm shift in banking: unfolding Asia's FinTech adventures. In Banking and Finance Issues in Emerging Markets (pp. 215-254). Emerald Publishing Limited. https://doi.org/10.1108/S1571-038620180000025010

Hang, C. C., Chen, J., \& Yu, D. (2011). An assessment framework for disruptive innovation. Foresight, 13(5), 4-13. https://doi.org/10.1108/14636681111170185

Hariyati, Tjahjadi, B., \& Soewarno, N. (2019). The mediating effect of intellectual capital, management accounting information systems, internal process performance, and customer performance. International Journal of Productivity and Performance Management, 68(7), 1250-1271. https://doi.org/10.1108/IJPPM-02-2018-0049

Hoechle, D. (2007). Robust standard errors for panel regressions with cross-sectional dependence. Stata Journal, 7(3), 281-312. https://doi.org/10.1177/1536867X0700700301

Jagtiani, J., \& John, K. (2018). Fintech: the impact on consumers and regulatory responses. Journal of Economics and Business, 100, 1-6. https://doi.org/10.1016/j.jeconbus.2018.11.002

Jagtiani, J., \& Lemieux, C. (2018). Do fintech lenders penetrate areas that are underserved by traditional banks? Journal of Economics and Business, 100(March), 43-54. https://doi.org/10.1016/j.jeconbus.2018.03.001

Jiang, C., Xu, Q., Zhang, W., Li, M., \& Yang, S. (2018). Does automatic bidding mechanism affect herding behavior? Evidence from online P2P lending in China. Journal of Behavioral and Experimental Finance, 20, 39-44. https://doi.org/10.1016/j.jbef.2018.07.001

Kohardinata, C., Soewarno, N., \& Tjahjadi, B. (2020). Indonesian peer to peer lending $(\mathrm{P} 2 \mathrm{P})$ at entrant's disruptive trajectory. 
Business: Theory and Practice, 21(1), 104-114. https://doi.org/10.3846/btp.2020.11171

Lee, I., \& Shin, Y. J. (2018). Fintech: Ecosystem, business models, investment decisions, and challenges. Business Horizons, 61(1), 35-46. https://doi.org/10.1016/j.bushor.2017.09.003

Levin, J., \& Milgrom, P. (2004). Consumer theory. https://web. stanford.edu/ jdlevin/Econ 202/Consumer Theory.pdf

Li, Y., Spigt, R., \& Swinkels, L. (2017). The impact of FinTech start-ups on incumbent retail banks' share prices. Financial Innovation, 3(1). https://doi.org/10.1186/s40854-017-0076-7

Lin, C., Li, B., \& Wu, Y. J. (2018). Existing knowledge assets and disruptive innovation: the role of knowledge embeddedness and specificity. Sustainability, 10(342), 1-15.

https://doi.org/10.3390/su10020342

Liu, J., Li, X., \& Wang, S. (2020). What have we learnt from 10 years of fintech research? A scientometric analysis. Technological Forecasting and Social Change, 155(March), 1-12. https://doi.org/10.1016/j.techfore.2020.120022

Ma, X., Sha, J., Wang, D., Yu, Y., Yang, Q., \& Niu, X. (2018). Study on a prediction of $\mathrm{P} 2 \mathrm{P}$ network loan default based on the machine learning LightGBM and XGboost algorithms according to different high dimensional data cleaning. Electronic Commerce Research and Applications, 31(June), 24-39. https://doi.org/10.1016/j.elerap.2018.08.002

Minto, A., Voelkerling, M., \& Wulff, M. (2017). Separating apples from oranges: Identifying threats to financial stability originating from FinTech. Capital Markets Law Journal, 12(4), 428-465. https://doi.org/10.1093/cmlj/kmx035

Montgomery, N., Squires, G., \& Syed, I. (2018). Disruptive potential of real estate crowdfunding in the real estate project finance industry: A literature review. Property Management, 36(5), 597-619. https://doi.org/10.1108/PM-04-2018-0032

Nguyen, T. Le, Vu Van, H., Nguyen, L. D., \& Tran, T. Q. (2017). Does rising import competition harm Vietnam's local firm employment of the 2000s? Economic Research, 30(1), 18821895. https://doi.org/10.1080/1331677X.2017.1392883

Otoritas Jasa Keuangan. (2019). Statistik Perbankan Indonesia Vol 17 No 11. https://www.ojk.go.id/id/kanal/perbankan/ data-dan-statistik/statistik-perbankan-indonesia/Documents/ pages/statistik-perbankan-indonesia---oktober-2019/SPI Oktober 2019.pdf

Pengnate, S. (Fone), \& Riggins, F. J. (2020). The role of emotion in P2P microfinance funding: A sentiment analysis approach. International Journal of Information Management, 54(April). https://doi.org/10.1016/j.ijinfomgt.2020.102138

Pérez, L., Paulino, V. D. S., \& Cambra-Fierro, J. (2017). Taking advantage of disruptive innovation through changes in value networks: insights from the space industry. Supply Chain Management: An International Journal, 22(2), 97-106. https://doi.org/10.1108/SCM-01-2017-0017

Pham, T., Talavera, O., \& Yang, J. (2019). Multimarket competi- tion and profitability: evidence from Ukrainian banks. Oxford Economic Papers, 1-29. https://doi.org/10.1093/oep/gpz041

Phan, D. H. B., Narayan, P. K., Rahman, R. E., \& Hutabarat, A. R. (2019). Do financial technology firms influence bank performance? Pacific-Basin Finance Journal, November 2, 1-13. https://doi.org/10.1016/j.pacfin.2019.101210

Pilloff, S. J. (1999). Does the presence of big banks influence competition in local markets? Journal of Financial Services Research, 15(3), 159-177. https://doi.org/10.1023/A:1008165132438

Ramlall, I. (2018). FinTech and the financial stability board. Understanding Financial Stability, 71-81.

https://doi.org/10.1108/978-1-78756-833-420181016

Rasool, F., Koomsap, P., Afsar, B., \& Panezai, B. A. (2018). A framework for disruptive innovation. Foresight, 20(3). https://doi.org/10.1108/FS-10-2017-0057

Romānova, I., \& Kudinska, M. (2017). Banking and Fintech: a challenge or opportunity? Contemporary Issues in Finance: Current Challenges from Across Europe, 98, 21-35. https://doi.org/10.1108/S1569-375920160000098002

Shawtari, F. A. M. (2018). Ownership type, bank models, and bank performance: the case of the Yemeni banking sector. International Journal of Productivity and Performance Management, 67(8), 1271-1289. https://doi.org/10.1108/IJPPM-01-2018-0029

Stern, C., Makinen, M., \& Qian, Z. (2017). FinTechs in China with a special focus on peer to peer lending. Journal of Chinese Economic and Foreign Trade Studies, 10(3), 215-228. https://doi.org/10.1108/JCEFTS-06-2017-0015

Tang, H. (2019). Peer-to-peer lenders versus banks: substitutes or complements? Review of Financial Studies, 32(5), 1900-1938. https://doi.org/10.1093/rfs/hhy137

Thakor, A. V. (2020). Fintech and banking: What do we know? Journal of Financial Intermediation, 41, 1-13. https://doi.org/10.1016/j.jfi.2019.100833

Wolfe, B., \& Yoo, W. (2017). Crowding out banks: credit substitution by peer-to-peer lending. SSRN Electronic Journal. https://doi.org/10.2139/ssrn.3000593

Wonglimpiyarat, J. (2017). FinTech banking industry: a systemic approach. Foresight, 19(6), 590-603. https://doi.org/10.1108/FS-07-2017-0026

Zakky. (2018). 34 Nama Provinsi di Indonesia dan Ibukotanya Lengkap. https://www.zonareferensi.com/provinsi-di-indonesia/

Zalan, T., \& Toufaily, E. (2017). The promise of Fintech in emerging markets: Not as disruptive. Contemporary Economics, 11(4), 415-430.

Zhang, Z., Hu, W., \& Chang, T. (2019). Nonlinear effects of P2P lending on bank loans in a Panel Smooth Transition Regression model. International Review of Economics and Finance, 59(August 2017), 468-473.

https://doi.org/10.1016/j.iref.2018.10.010 